\title{
Rosalie Kunoth-Monks and the making of Jedda
}

\author{
Karen Fox
}

Filmmaker Charles Chauvel described the casting for Jedda, released in Australia in 1955, as 'a unique experiment'. He referred to the casting of two Aboriginal people, who had never acted before, as the film's stars. Much scholarship has examined the film itself, analysing its themes and its representations of Aboriginal people. Less attention has been paid to the ways in which its Aboriginal stars, Rosalie Kunoth-Monks and Bob Wilson, experienced starring in the film. ${ }^{1}$ This paper focuses on Kunoth-Monks, who was for a brief time widely known and acclaimed throughout Australia, and whose starring role continued to be remembered throughout her life, even as she moved into areas of activity far removed from the film industry. ${ }^{2}$ Writing on the practice of film history, Barbara Klinger has advocated an approach which seeks to provide a 'total history' through investigating 'a film's "ancillary" texts' (for example, promotional material and popular media texts). ${ }^{3}$ For historians interested in filmic representations of, by or for Indigenous peoples, the narratives found in texts surrounding the participation of Indigenous peoples in filmmaking can be as rich as the films themselves for analysis. In this paper, I critically explore narratives about Kunoth-Monks' experience of filmmaking, and recurring representations of her, which appeared in the popular print media, in publicity material for the film and in the memoirs of Chauvel's wife and filmmaking partner, Elsa, as well as Kunoth-Monks' own memories. Exploring her brief time as a film star provides insight not only into the film and the Chauvels' attempt to represent Aboriginal people on film, but also into the ambiguous and sometimes uncomfortable experience of being simultaneously a traditional Aboriginal woman and a film star.

\section{Creating sensations and stars}

With his wife Elsa, Charles Chauvel made several films, all displaying his intense nationalism and love of Australia's landscape. Many of his films centred on pioneering life in the bush, the achievements and spirit of the Australian military or relations between cultures. ${ }^{4}$ Among these were pioneer tales such

1 Exceptions include: McQueen 2005: 60-63; Schlunke 1993: 9-13.

2 Note that, although Kunoth-Monks was still Rosie Kunoth when Jedda was filmed, KunothMonks being her married name, I have referred to her throughout as Kunoth-Monks to avoid confusion.

3 Klinger 1997: 107-128, cited in Landman 2006: 5.

4 Molloy 1990: 103. 
as Sons of Matthew (1949), the patriotic films Forty Thousand Horsemen (1941) and Rats of Tobruk (1944), and the melodrama Uncivilised (1936), in which a white woman becomes caught up in a tribal war. During his career, Chauvel also showed interest in representing Indigenous people on film, and in filming on location in difficult places. Stuart Cunningham, who has provided the most extensive analysis of Chauvel's filmmaking, observed the existence of a 'general consensus' among scholars that Chauvel's work represents 'the most avowedly nationalist filmmaking in Australia'. ${ }^{5}$

The impetus for making Jedda, Chauvel's last film, came from a conversation he had while in the United States. Over coffee in a New York restaurant, a journalist with Time magazine suggested that he make a movie that was not possible elsewhere, and that he have Aboriginal people act in it. ${ }^{6}$ Making the decision to partly base the plot on fact, he and Elsa blended three 'authentic tales of the outback' to create the story of Jedda, an Aboriginal girl brought up by a white station owner's wife after her own child dies. ${ }^{7}$ Jedda feels drawn to her Aboriginal heritage, and allows herself to be sung to the campfire of Marbuk, a supposedly uncivilised newcomer to the station, despite the desire of the part-Aboriginal head stockman, Joe, to marry her. Presenting Jedda as driven by natural tribal instincts that had previously been suppressed in her, the film suggests that primitivity, or 'blood', must trump education and civilisation, making assimilation an impossibility. The story ends in tragedy after Marbuk abducts Jedda and takes her to his country, where he is sung to death by his own tribe for bringing back a girl of the wrong tribal group, and leaps to his death off a cliff, pulling Jedda with him. Released in 1955, Jedda starred Rosalie Kunoth (as she then was) and Bob Wilson, billed as Ngarla Kunoth and Robert Tudawali.

A strong publicity campaign preceded the release of Jedda. Considerable publicity usually attended Charles Chauvel's films, particularly those which appeared later in his career, and the 'sagas' of making them thus became 'as well known as the films themselves'.$^{8}$ Before Jedda was released, coverage of the forthcoming film appeared in a range of media, from trade papers such as the Film Weekly to women's magazines such as the Australian Women's Weekly, and from the New South Wales government's Aborigines Welfare Board publication Dawn to the geographic magazine Walkabout. Some of this promotional material reflected elements of the 'biographical legend' about Chauvel which Cunningham has identified. This myth portrayed Chauvel as an 'established producer of quality films' who disdained 'quickies', and as a heroic and 'independent' filmmaker who battled against difficulties to produce uniquely Australian films. ${ }^{9}$ In the publicity material which preceded the release of Jedda, the choice to involve Aboriginal stars was touted as a source of uniqueness which gave the film curiosity value. Chauvel noted in a progress report on filming in The Film

5 Cunningham 1991: 19.

6 Chauvel 1973: 115.

7 Carlsson 1989: 151.

8 Cunningham 1987: 28, 1991: 148.

9 Cunningham 1991: 3, 156-157. 
Weekly in 1952 that one of the 'native talent' then being screen-tested would be chosen to play the character of Jedda. 'Our casting is a unique experiment', he wrote, 'and one which I hope will capture the interest of filmgoers throughout the world' ${ }^{10}$ Even before the film appeared, its Aboriginal stars were thus placed as a potential source of public curiosity and attention.

\section{Becoming Jedda}

Rosalie Kunoth-Monks was born in a river bed on Utopia Station in Central Australia, the daughter of Alan and Ruby Kunoth. ${ }^{11}$ Ruby was a traditional Aboriginal woman from Utopia Station, and Alan was of German and Aboriginal descent. As a child, Rosalie travelled between stations while Alan worked as a shearer, managing to stay with her family at a time when other children were being taken. ${ }^{12}$ Raised in a traditional Aboriginal way, she did not learn English until her parents wished her to attend school in Alice Springs, where she stayed at St Mary's Hostel for Aboriginal children. ${ }^{13}$ Kunoth-Monks was still at school when she was cast as Jedda. On their second visit to St Mary's in search of a girl to play the role, the Chauvels decided that none of those selected by the nuns to meet them were suitable. In her memoirs, Elsa described spotting KunothMonks just as she and her husband were on the point of departure. She drew his attention to her, remembering 'an elfin looking face with large velvety brown eyes and soft, long wavy hair' watching from behind a tree. ${ }^{14}$ Kunoth-Monks was soon on her way to Coolabah for screen tests. In an interview given later in her life, she remembered Charles commenting upon her shyness during the screen test. She recalled that he had considered shyness to be 'the trait of the Aboriginal woman' and that he had spoken of her as 'the more traditional' of those who were screen-tested..$^{15}$ Looking back, she believed that she was given the role of Jedda because she seemed 'closer to the traditional Aboriginal' in both 'mannerism' and appearance. ${ }^{16}$ In her turn, Elsa remembered screentesting 'some very attractive girls', but finding them 'too inter-mixed and too far removed from the primitive that we were looking for' ${ }^{17}$ As they sought a girl to play Jedda, the Chauvels thus hoped to find someone who could embody both primitive mystery and modern film star beauty.

Between 1940 and 1956, documentary ideals were highly influential in the film industry. ${ }^{18}$ In much of Charles Chauvel's filmmaking, including Jedda, 'a "documentary" impulse' was clearly evident, although his work remained

10 Charles Chauvel, 'Progress report on "Jedda"', The Film Weekly, 18 December 1952: 52.

11 Chryssides 1993: 176.

12 Monks 1988: 132.

13 Kunoth-Monks, interview with Hughes, 10-12 July 1995, Utopia, Northern Territory [hereafter interview], tape 1 .

14 Chauvel 1973: 125.

15 Chryssides 1993: 181.

16 Kunoth-Monks, interview, tape 2.

17 Chauvel 1973: 122.

18 Cunningham and Routt 1989: 181. 
'myth-making' in his efforts to express the essence of Australia and the Australian character. ${ }^{19}$ Publicity material, as well as the narration at the beginning of Jedda, emphasised the film's authenticity - that it featured people from the Northern Territory reprising their real lives, and that research had been undertaken into Aboriginal lives and customs. ${ }^{20}$ Chauvel had been advised by long-time Territory resident Bill Harney, who had resigned from a post as a patrol officer several years before to focus on writing. Harney's wife Linda was of Aboriginal descent, and he greatly enjoyed Aboriginal company, learning a great deal about Aboriginal lifeways. ${ }^{21}$ When Jedda was released in 1955, several commentators recognised its documentary qualities. In the Weekly Times, 'M. S.' termed it 'a most unusual study of primitive and modern existence' which showed 'aspects of life in the interior' which had 'never before been seen' on film, with 'authentic backgrounds' and 'strictly correct' depictions of Aboriginal life. ${ }^{22}$ A reviewer for the Adelaide Advertiser considered that the film was 'substantially authentic', showing the 'vastness' and beauty of the Territory and the 'life and character of the aborigines', who were described as 'the world's oldest race in one of the oldest countries, in which the white man has only begun the process of development and civilisation'. ${ }^{23}$ Dawn magazine praised the film's educative possibilities and potential for societal improvement. It observed:

As many Dawn readers live in big cities or on board Stations, they will find much of 'Jedda' as strange and unusual as will the white population ... but ... nothing has been exaggerated, nothing distorted, nothing garbled..$^{24}$

Such understandings of the film emphasised its documentary aspects as a work that provided a glimpse into a remote and mysterious place and an ancient way of life which was becoming lost, rather than its qualities as a dramatic narrative.

The Aboriginal stars of Jedda were also depicted in ways which stressed their status as bona fide Aboriginal people, and thus the authenticity of the film. In a promotional booklet titled Eve in Ebony, Kunoth-Monks was described as 'a genuine aborigine' and as 'primitive' ${ }^{25}$ Reference was made to her descent as a member of the Arunta (Arrernte) people in publicity material and the print media. In search of authenticity, she wore dark make-up for the film, so that she did not look too fair-skinned beside Wilson. ${ }^{26}$ She was named Ngarla in the credits of the finished movie, Elsa Chauvel having told her that Rosalie, Rose and Rosie were not sufficiently Aboriginal. Elsa had therefore chosen Ngarla, her mother's skin name, despite Kunoth-Monks' unhappiness at the false

19 Cunningham 1987: 33-34; Cunningham and Routt 1989: 180.

20 Cunningham 1991: 157-158.

21 Kennedy nd.

22 'M. S.' , 'Best Australian film so far', Weekly Times, 7 September 1955: 92.

23 A Correspondent, 'Film "Jedda" is gripping', Advertiser, 5 January 1955: 5.

24 'Jedda is YOUR film', Dawn 3(9), September 1954: 8.

25 Chauvel et al c1954.

26 Chryssides 1993: 185. 
idea thus given of the marriage line appropriate to her. ${ }^{27}$ For Kunoth-Monks, this interchange was the moment when she and Elsa 'fell off from each other', because 'I'd been brought up knowing who I am, and for a white person to change my skin was more than I could take' ${ }^{28}$ Katrina Schlunke has argued that, although the practice of adopting a screen name was not unusual in itself, the re-naming of Kunoth-Monks as Ngarla constituted 'the flower arranging version of Aboriginality', as the Chauvels had sought a name that would seem more appropriately Aboriginal to white filmgoers. ${ }^{29}$ Emphasising the authenticity of the name, the promotional booklet Eve in Ebony asserted that 'Rosie' was Kunoth-Monks' 'Christian name', while 'Ngarla' was 'the old tribal name she went under as a small girl, wandering barefoot and ragged through the sandy wastes of Central Australia' ${ }^{30}$ At the same time, Charles wrote of his delight in having found a girl who was 'free of tribal restrictions' to play the role. He explained that he had frequently been informed that it would be 'impossible to find a girl from the aborigine womenfolk who would have the confidence, or who would be de-tribalised enough to act for us'. 'It is part of the everyday living of the Australian aborigine', he wrote, 'that the woman is a mere chattel' and subject to 'old tribal taboos' and superstitions, at least while young. ${ }^{31}$ The authentic Aboriginality symbolised by the name 'Ngarla' was thus linked to primitivism, superstition, poverty and abjection, the sub-text being that 'Rosie' had been rescued from this situation by the advent of Western civilisation and Christianity, in the form of the Chauvels and their filmmaking venture.

\section{Making the film}

Kunoth-Monks remained away from home for some time during filming. In her recollections of making the film, Elsa Chauvel reasonably stressed the difficulties involved in making the film, such as handling the delicate colour film in the heat of the Territory, camping and working with untrained actors. Her account envisioned the filmmaking as a heroic endeavour, with Charles as the hero, and herself the helpmate at his side. The Chauvels' daughter, Susanne Chauvel Carlsson, wrote a later account with similar overtones, imagining her parents as having faced 'the hardships of pioneers'.$^{32}$ Remembering her relationship with Kunoth-Monks, Elsa placed herself as a maternal figure, relative to Kunoth-Monks' childish primitivity, often using imagery reminiscent of nature and animals. Elsa wrote that Kunoth-Monks was 'a shy, rather clumsy and inarticulate child at first', but under her protection she 'soon gained confidence and would romp around the camp like an excited puppy, or curl at my feet as I sat doing the script notes' ${ }^{33}$ Promotional material described her in similarly

27 Chryssides 1993: 183-184.

28 Kunoth-Monks, interview, tape 3.

29 Schlunke 1993: 11.

30 Chauvel et al c1954.

31 Chauvel et al c1954.

32 Carlsson 2005: 52.

33 Chauvel 1973: 129. 
de-humanising terms as 'one of the most beautiful specimens of her race', a comment which carried echoes of earlier discourses of racial science. ${ }^{34}$ Elsa's unconscious ideal of white womanhood was also evident in her remembrance of her role as a peacemaker between Kunoth-Monks and Charles when KunothMonks refused to do what she had been asked to do. While he was 'desperate and frustrated', Elsa remembered having taken Kunoth-Monks 'away for a while' to 'talk it out', and noted that the issue was often that she had been asked to act in a way that was contrary to 'tribal custom', thus necessitating 'a slight alteration ... to the script'. At other times, the issue was that Wilson was to touch Kunoth-Monks, who was worried that Wilson's wife would be angry. ${ }^{35}$ Far from being 'free of tribal restrictions', Kunoth-Monks was clearly well-schooled in the laws of her people, and perhaps surprisingly, she was also able to exert at least some influence on the final shape of the film through her position as a traditional person.

Kunoth-Monks' memories of making the film were very different in emphasis from those of Elsa Chauvel and Susanne Carlsson. She recalled her dislike of being taken away from her place and people to unfamiliar country and to a 'situation where you didn't have any control whatsoever', and her 'most prominent feeling' during filming was 'homesickness'. ${ }^{36}$ She was not informed that she was to play Jedda in the film, but was simply given instructions to care for her appearance. ${ }^{37}$ During the first three months, she did not know what the cameras were doing, thinking Charles Chauvel and the cameraman were 'a temperamental lot' because they complained that 'the sun wasn't shining in the right place, or that someone was casting a shadow' ${ }^{38}$ Rather than recalling Elsa as the peacemaker, she had 'very fond memories' of Charles 'smooth[ing] the ruffled feathers on both sides: his wife's and mine' ${ }^{39}$ Elsa she remembered as 'the bully-lady', who made her diet to achieve a sufficiently slim appearance and gave her a 'smack ... for sucking my thumb and for being shy'. ${ }^{40}$ At the same time, she acknowledged that Elsa was 'the taskmaster' who 'had to get it done', and that she was 'responsible' both for 'the outcome of [the] film' and for Kunoth-Monks herself. When filming moved to Sydney, Kunoth-Monks lived in the Chauvel household. This experience she later described as relatively comfortable, although she did recall instances of difficulty. One such was when she wanted to play. 'Sometimes I rolled on the front part of their lawn, playing, just being boisterous', she remembered, remarking that such behaviour 'was a bit out, because young girls were brought up to behave in a certain way in the 1950s, whereas that wasn't the way I was brought up'. Another was at the dinner table, where it was 'out of the ordinary that this little savage, brown girl was

34 Chauvel et al c1954. For more on the discourses of racial science, see Anderson 2007; Douglas and Ballard 2008; McGregor 1997.

35 Chauvel 1973: 129.

36 Chryssides 1993: 183; Kunoth-Monks, interview, tape 2.

37 Chryssides 1993: 181.

38 Chryssides 1993: 181-182.

39 Kunoth-Monks, interview, tape 2.

40 Chryssides 1993: 182; Kunoth-Monks, interview, tape 2. 
chewing on the bones at the table' ${ }^{41}$ Despite the difficulties of their relationship, however, Kunoth-Monks did not have strongly negative feelings towards the Chauvels.

In her memoirs, Elsa Chauvel remembered similar aspects of Kunoth-Monks' stay with the family to those recalled by Kunoth-Monks herself. Like KunothMonks, Elsa emphasised a cultural clash in some of the incidents she recounted, but she placed a different complexion upon these events. 'It must have been a strange experience' for Kunoth-Monks, she wrote, and it was 'quite an experience for us $^{\prime}{ }^{42}$ Elsa described Kunoth-Monks' pleasure in bubble bath, her dislike of foods such as asparagus and broccoli, and having 'watched with amazement Ngarla crunch and crunch a lamb knuckle until there was not a particle left' ${ }^{43}$ Kunoth-Monks' playing on the lawn was also described. She had been dressed for church, appearing 'so attractive with not a button or a bow out of place', and had returned home to be 'within five minutes ... tumbling and rolling all over the lawn like a wild puppy, until her dress was a rag and her brown legs a mass of scratches' ${ }^{44}$ Elsa also noted that Kunoth-Monks 'would curl up on the floor and tell us strange stories of her childhood', and Carlsson likewise later wrote of having been 'entertained through dinner with hair-raising tales of [KunothMonks'] tribal days'. ${ }^{45}$ In these recollections, the mystery, strangeness and violence of tribal and outback life were emphasised. Yet Elsa and her husband appeared to view Aboriginal people relatively positively, refusing to believe that they could not make good actors. At the same time, Elsa's recollections of making Jedda clearly placed Charles and herself in a parental position relative to the Aboriginal people who had worked with them on the film. On leaving the Territory, she recalled:

Our little families of aborigines lined up to say goodbye, each clutching our farewell gifts and crying like children. Charles and I felt the parting equally as much as these loyal people had worked beside us and given of their best. It was like parting with members of our own family. ${ }^{46}$

In this passage, the praise for the loyalty of the Aboriginal workers evokes the faithful Jacky Jacky figure, a stereotypical caricature of Aboriginal people who had assisted early European explorers.

\section{The premiere night}

Once filming was over, Kunoth returned to Alice Springs and had 'forgotten about' the film until the premiere, held in Darwin's Star Theatre. ${ }^{47}$ It was a

41 Kunoth-Monks, interview, tape 2.

42 Chauvel 1973: 138.

43 Chauvel 1973: 138-139.

44 Chauvel 1973: 139.

45 Carlsson 2005: 52; Chauvel 1973: 138.

46 Chauvel 1973: 136.

47 Chryssides 1993: 187. 
big event, the city's first world premiere. The theatre foyer, from which ABC presenter Peter Lee gave 'a spot broadcast', was 'decorated with pandanus palms and aboriginal curios' ${ }^{48}$ Crowds waited outside to see the more than 200 invited guests arrive in formal attire. ${ }^{49}$ The Film Weekly, presumably referring only to white Australians, commented that '[p]ractically every inhabitant of the northern city turned out to see the first showing' of the film. ${ }^{50}$ Kunoth-Monks' dress was described in many media accounts, placing her within the discourse of glamour around a movie star and a premiere. She 'looked very charming', thought the Northern Territory News, while Elsa commented that she 'looked a dream of a girl' and that 'her quite simple deportment gained the admiration of all' ${ }^{51}$ Kunoth-Monks herself recalled that she 'looked like a princess, or a queen' as she had read about in children's books. ${ }^{52}$ She stated that as she had experienced filming as 'hard work and not being able to do my own thing', the premiere night was when she 'first ... realised this thing was putting me in an enviable position' ${ }^{53}$

The glamorous discourse that Kunoth-Monks was placed within was what might be expected for a white film star, and she did not consider it entirely negative. She stated later that 'it became almost glamorous to be an Aboriginal person'. 'There was an Aboriginal girl standing up there looking nearly as good as Marilyn Monroe', she recalled, and 'acting the same way'. ${ }^{4}$ Kunoth-Monks' attractive appearance was often mentioned in the media around the time the film was released. Several references were made to her skin colour, as 'a brownskinned beauty', a 'comely chocolate heroine' or as having 'dark loveliness' ${ }^{55}$ These comments called on her descent from an ancient tribe to add mystery to the glamour. However, such depictions were significantly outnumbered by comments on her prettiness that did not mention her colour, subsuming her race under a focus on beauty and femininity. Part of her appeal was also the charming shyness sometimes reported. Soft voices and timidity were considered attractions of Aboriginal women in the earliest days of contact. ${ }^{56}$ Such descriptions imagined Aboriginal women within 'European aesthetic traditions'. ${ }^{57}$ Media descriptions of Kunoth-Monks in the 1950s imagined her within Hollywood aesthetic traditions, even while deploying the idea of the exotic as an attraction. The juxtaposition of exoticism and glamour was occasionally recalled in later articles about Kunoth-Monks' life. In 1971, John Sorell described her in the

48 'Colour, excitement at premiere', Northern Territory News, 6 January 1955: 1.

49 Brister 1995: 40.

50 ““Jedda's” spectacular premiere!', The Film Weekly, 13 January 1955: 12.

51 'Jedda night caught the imagination', Northern Territory News, 6 January 1955: 5; Chauvel 1973 : 146.

52 Chryssides 1993: 187; Kunoth-Monks, interview, tape 3.

53 Chryssides 1993: 187.

54 Chryssides 1993: 189.

55 Joyce Burns Glen, 1954, 'On the rugged trail of “Jedda"', New York Times, 31 January 1954: 5; Brian McArdle, 'Jedda opens new cinema field', Age, 24 August 1955: 2; “"Jedda's” spectacular premiere!', The Film Weekly, 13 January 1955: 12.

56 McGrath 1990: 197-199.

57 McGrath 1990: 202. 
Melbourne Herald as 'quite a dame', having become 'matronly' at 34 years of age, but still having the 'flashing eyes and the mischievous smile and dusky allure that entranced, captivated and excited Australia 18 years ago'.$^{58}$

In reports of the premiere night, the Aboriginality of the lead actors was most clearly foregrounded in a discussion about where they sat for the showing, since the Star was at that time a segregated theatre, as well as in relation to their acting ability. The Northern Territory News claimed that Wilson and Kunoth-Monks were both 'conducted to special seats in the dress circle', while the Daily Telegraph's story was that Wilson and his wife sat downstairs with the other Aboriginal attendees, Wilson having stated he did not want to sit upstairs, although on the night he wished he had.$^{59} \mathrm{~A}$ similar report was made in the Adelaide Advertiser, which also noted that '[f] ewer than 20 natives - each selected - watched the first screening of the picture', and that Aboriginal people were generally only able to go to the theatre on Wednesday nights. ${ }^{60}$ Kunoth-Monks also remembered that she had sat upstairs while Wilson and his wife sat downstairs, adding that there 'was a difference there, but I wasn't aware of it on the night' ${ }^{61}$ In 2000, the Northern Territory News explained that Wilson was:

publicly demonstrating that he was an Aborigine and would remain one despite official hopes that he would be an early and spectacular example of successful Aboriginal assimilation and achievement in the white world. ${ }^{62}$

His sitting downstairs, negative at the time, was thus re-imagined as an act of solidarity with other Aboriginal people. Kunoth-Monks herself, asked in later life why she was 'made an honorary white on the night', speculated that it was because she was from elsewhere, and suggested that 'Bob probably chose to sit with his people, which was probably his stance ... if it happened in Alice Springs I would have said, "No, I'm sitting with my mum", and gone down'. ${ }^{63}$

Although Kunoth-Monks reportedly told the Advertiser after the event that she had enjoyed the film, her later comments suggest that this was not the case. She said in an interview for the television programme Australian Biography that she was given:

a little paper saying, 'I hope you all enjoy the film as much as I did making it' ... So that's what I said. If it had been left to me I would have said, 'I hated making this bloody film. I hope you enjoy it more than I did', you know. $^{64}$

58 John Sorell, “'I cry a little about the Alice”', Herald, 15 November 1971: 2.

59 'No one noticed star of "Jedda"', Daily Telegraph, 4 January 1955: 8; 'Colour, excitement at premiere', Northern Territory News, 6 January 1955: 1.

60 'Stars see "Jedda"', Advertiser, 4 January 1955: 17.

61 Kunoth-Monks, interview, tape 3.

62 'Tragedy of Tudawali', Northern Territory News, 12 December 2000: 28.

63 Kunoth-Monks, interview, tape 3.

64 Kunoth-Monks, interview, tape 3. 
Because scenes were not filmed in the order in which they finally appeared, she did not understand the plot of the film whilst making it. When she saw the finished product that night she was unhappy and ashamed. The behaviour of the character of Jedda irritated her as she watched the plot unfold. 'I kept saying: "that woman there, she's stupid, she should run now"', she recalled in a later interview..$^{65}$ She remembered seeing 'a very suggestive scene' in the film, and commented that ' $[\mathrm{t}]$ he first thing that came into my head was "what's Mum going to think?"', as her mother might have thought it 'real'. ${ }^{66}$ Speaking on the Australian Broadcasting Corporation (ABC) television programme Message Stick in later life, she explained that according to her 'grandmothers' law' she 'was not to talk [to] or look at this strange man' (Wilson), but she was made to raise her head to do so, leaving her 'ashamed' because '[t]hey slowly broke my law to make me act'. ${ }^{67}$ The Chauvels' inability to understand this was evident in the comments of Charles in Eve in Ebony, as he explained that trying to cast Jedda 'became disheartening, because we were trying to make women, who had been hopelessly suppressed for thousands of years, "emote" freely before the cameras' ${ }^{68}$ While the Chauvels did not accept the popular prejudice that Aboriginal people could not be actors, this comment displays a lack of understanding of Aboriginal culture and customs, and a continuing belief in Aboriginal primitivity.

\section{The reception of the film}

At the time of the film's release, positive reviews outnumbered negative. ES Madden in the News-Weekly considered it 'highly successful' and able to 'hold its own with the best from any studio in the world', while the Weekly Times thought it ' $[\mathrm{u}]$ ndoubtedly the best film produced in Australia' ${ }^{69}$ An important aspect of many positive responses was the film's status as unusual. In a special section about Jedda in The Film Weekly, it was described as being 'big boxoffice' because it was 'something completely different' and a film that 'could only have been made in Australia'. In relation to its uniqueness, the unnamed author of the article noted both that ' $[\mathrm{t}]$ he magnificent backgrounds have in most instances never been photographed before' and that ' $\mathrm{t}]$ he casting is revolutionary: two Australian aborigines in a $\square 100,000$ gamble on their ability to act'. ${ }^{70}$ A reviewer in the Advertiser noted that Jedda was 'expected to arouse great interest' because it was unusual. ${ }^{71}$ Not everyone greeted the film with rave reviews, however. One reviewer for the Northern Territory News saw it as '[d]ramatically unsound', drew attention to 'flaws in Chauvel's direction' such as a 'lack of dialogue' and

65 Chryssides 1993: 188.

66 Chryssides 1993: 183.

67 'Rosalie's Journey', Message Stick, 18 February 2005.

68 Chauvel et al c1954.

69 ES Madden, '“Jedda” could begin a new Australian era', News Weekly, 12 October 1955: 7; 'M. S.', 'Best Australian film so far', Weekly Times, 7 September 1955: 92.

70 'Salute to "Jedda"', The Film Weekly, 14 April 1955: special section, A.

71 A Correspondent, 'Film "Jedda" is gripping', Advertiser, 5 January 1955: 5. 
commented on the sometimes 'amateurish acting'. ${ }^{72}$ Gerry Grant in the leftleaning Overland thought the film 'thoroughly bad', arguing that it 'peddles the worst kind of racist nonsense' as well as being 'technically and artistically thirdrate'. Grant's criticism centred on the film's implicit suggestion that assimilation was not possible, which he saw as evidence of the Chauvels' belief in Aboriginal 'inferiority'. ${ }^{73}$ Later readings of Jedda which were more approving of its antiassimilation stance presumably reflected a changing policy climate and shifting societal beliefs. Overseas, the New York Times reviewer appeared to simply find the film baffling. Jedda ran away with 'a weird-looking tribal barbarian' because of 'some rather obscure reason', the reviewer wrote, unable to grasp her having swapped a 'happy' future '[f]or this frightening specimen'.$^{74}$

A number of reviewers placed the Aboriginal actors with the scenery as highlights of the film, giving an impression of Aboriginal people as natural attractions of Australia along with its landscapes. One such was Brian McArdle, writing in the Age. He considered that Jedda brought the 'remote, virtually uncharted regions and peoples of northern Australia' to film 'not as museum curiosities, but as living human beings', and commended Charles Chauvel for his focus on the 'comely chocolate heroine', the 'black hero-villain' and the 'dramatic landscapes of the Northern Territory'.$^{75}$ This association of Aboriginal people with naturalness was also apparent in comments on their supposed natural acting ability. Charles described Kunoth-Monks as 'beautiful, intelligent and a born actress'.$^{76}$ Madden thought she and Wilson both had 'the instinctive sense of the dramatic so characteristic of their race', and 'M.S.' in the Weekly Times stated that they were '[1]ike most Australian natives ... born mimics', whose 'almost flawless portrayals ... show how their natural talents have responded to clever direction' ${ }^{77}$ The idea that Aboriginal people were 'apparently a race of natural actors' also appeared in the London Times, praising Wilson. ${ }^{78}$ The Film Weekly's reviewer, while less impressed by the acting performances, was more explicit about placing Aboriginal people with nature and the animal world, commenting that 'through sheer animal magnificence, Robert Tudawali emerges as a strong screen personality', giving him little credit for any acting craft. ${ }^{79}$ Ironically, Kunoth-Monks herself remembered her acting as natural in a rather different way, explaining that 'most of the emotions' she was asked to act 'were fear anyway, so it was natural' ${ }^{80}$

Later understandings of the film varied widely. Several aspects led commentators to see it as innovative or daring. It was the first film by an

72 Bill Tuckey, 'Jedda- and the platypus', Northern Territory News, 6 January 1955: 7.

73 Grant 1956: 7.

74 'H. H. T.' ,'Screen: down under', New York Times, 28 February 1957: 18.

75 Brian McArdle, 'Jedda opens new cinema field', Age, 24 August 1955: 2.

76 Chauvel et al c1954.

77 ES Madden, “'Jedda” could begin a new Australian era', News Weekly, 12 October 1955: 7-8; 'M. S.', 'Best Australian film so far', Weekly Times, 7 September 1955: 92.

78 Our Correspondent, 'A Northern Territory film premiere', Times, 5 January 1955: 5.

79 'Reviews', The Film Weekly, 12 May 1955: 13.

80 Kunoth-Monks, interview, tape 3. 
Australian shot in Australia in colour, with unstable Gevacolor film that had to be sent to London for processing, and was the first Australian entry to the Cannes Film Festival. ${ }^{81}$ For the first time, Aboriginal people were given star status as actors in the two lead roles, despite having no training as actors, roles for which they became celebrated and remembered while white members of the cast were forgotten. ${ }^{82}$ Alan McKee summed up the variety in readings of the film as falling into at least two totally opposed views, 'simplistically glossed as "good Jedda/bad Jedda"'.83 The film was produced in a time when the ability of Aboriginal people to assimilate, as was promoted by government policy, was fervently debated. Jeremy Beckett was one of many commentators to consider the film 'an explicit critique of assimilationism' ${ }^{84}$ Colin Johnson (later known as Mudrooroo) thought the film of interest because Aboriginal people were 'not relegated to a romantic backdrop' but were 'allowed to be centred in the film' ${ }^{85}$ Marcia Langton, on the other hand, thought it 'sickening' racist nonsense. ${ }^{86}$ Paul Watson has noted that the film was '[a]necdotally, ... hugely popular with Aboriginal audiences' ${ }^{87}$ Kunoth-Monks herself, looking back, praised its antiassimilation stance. She commented that:

I think it was a very brave thing for Mr. and Mrs. Chauvel to do. I appreciate the Aboriginal context ... and I also appreciate the story line itself ... [b]ecause in my life time I've seen so many children taken into care by policies, by the government ... and that failing and miserable adult trying to come back and trying to find their roots. ${ }^{88}$

While the film came to be considered an Australian classic, many critics clearly remained ambivalent about its messages and divided over its portrayals of Aboriginal people.

\section{Jedda the assimilated?}

Curiously, given the anti-assimilation slant of the film, publicity material and articles about it in 1954 and 1955 sometimes depicted Kunoth-Monks and Wilson themselves as assimilation successes. Wilson was profiled in the publicity booklet Eve in Ebony under the headline: 'Robert Tudawali - civilised savage', while Kunoth-Monks was said to have been 'taken' to St Mary's Hostel in Alice Springs and 'raised in the ways of the white people' while she was 'still young enough to be taught'. ${ }^{89}$ Dawn magazine described the stars as 'two

81 Carlsson 1989: 151-152, 2005: 51-52; Walsh 2005: 55.

82 Among those who have claimed the film was path-breaking, daring or a first for this reason are: Ackland 2001: 18; Beckett 1993: 15; Carlsson 2005: 51; Haskins 2001-2002: 98.

83 McKee 1997: 116.

84 Beckett 1993: 16. Karen Jennings likewise argued that the 'preferred reading' of the film should be as 'an anti-assimilationist text', Jennings 1993: 36-37.

85 Johnson 1987: 47.

86 Langton 1993: 47.

87 Watson 1996: 16.

88 Kunoth-Monks, interview, tape 3.

89 Chauvel et al c1954, original emphasis. 
typical Australians, hard working and good living' and 'a credit to their race'.$^{90}$ Despite Kunoth-Monks' lack of knowledge about films, Dawn claimed that she had a 'favourite film star', Stewart Granger, just like 'white girls her age' ${ }^{91}$ At the same time, promotional material in the 1950s continued to emphasise her difference. The booklet Eve in Ebony ended its profile of her with the comment that she 'retains the age-old, primitive emotions of her race, and will always be a somewhat unknown quantity with her charming will-o'-the-wisp quality'. ${ }^{92}$ Contrasting these discourses, Kunoth-Monks herself prosaically recalled that she had learnt at a young age that she 'belonged to both sides', due to her father's German-Aboriginal descent, and she believed she had 'learned to straddle the two worlds' ${ }^{93}$ She expressed her anger when people would not provide her the same courtesy: 'If I drop my h's, or whatever, or use my colloquialisms which is 'this mob' or 'that mob', I am looked on as not quite civilised, and it makes me angry' ${ }^{94}$ For her, discourses of civilisation and otherness were not selling points for a movie, but sources of hurt and frustration that impinged on her life.

Writers of promotional material for the film in the 1950s forecast a future for Kunoth-Monks in which she would represent the abilities and worth of Aboriginal people to white society. Quoting from Eve in Ebony once again: 'Ngarla Kunoth, beautiful aborigine girl, has become a proud ambassadoress of one of the greatest aborigine races in the world'.$^{95}$ Dawn also took up this refrain, contending that having 'proved herself a very talented actress as well as a charming young Australian woman', there was 'no doubt' that she would 'bring a great deal of very favourable publicity to the aboriginal people' ${ }^{96}$ KunothMonks did become an important political voice later in her life, not as a role model of assimilation, but as a strong leader among her own people in her own country. After Jedda, she returned to Alice Springs for a time, before joining the Anglican Community of the Holy Name in Melbourne. Receiving a dispensation from her vows, she left the convent some years later when she began to feel that she had become estranged from her people. As she learned of the experiences of Aboriginal people, observed corruption in places of authority and discovered the misery on Melbourne streets, she became aware of problems that needed solutions. ${ }^{97}$ After leaving the convent, she took a job as an Aboriginal Liaison Officer in the Department of Aboriginal Affairs in Melbourne. On her return to Alice Springs in 1977 to operate the Ayiparinya Aboriginal Hostel, she saw great change since she had left, which she described as 'cultural genocide' wrought by alcohol, loss of culture and country, racism and bureaucratic problems in Aboriginal Affairs. ${ }^{98}$ She increasingly spoke out about the issues she observed. Becoming involved with the Country Liberal Party, she twice ran unsuccessfully

90 'Jedda is YOUR film', Dawn 3(9), September 1954: 10.

91 'Jedda is YOUR film', Dawn 3(9), September 1954: 9.

92 Chauvel et al c1954.

93 Chryssides 1993: 179; Rintoul 1993: 331.

94 Rintoul 1993: 332.

95 Chauvel et al c1954.

96 'Our cover', Dawn 3(10), October 1954: contents page.

97 Kunoth-Monks, interview, tape 4.

98 Chryssides 1993: 196; Kunoth-Monks, interview, tape 5. 
for office in the Northern Territory seat of Macdonnell. Hindsight made her 'glad' later in life to have lost these elections, as she had 'discovered ... that the policies of the party control you' ${ }^{99}$ Her involvement with government continued in her time as Ministerial Officer to Paul Everingham, the first Chief Minister of the Territory, until a plan to flood a sacred site made it impossible for her to continue in that position. ${ }^{100}$ Kunoth-Monks has held many important positions in relation to Aboriginal affairs, including in the Aboriginal Development Commission, the Central Australian Aboriginal Legal Aid Service and the Aboriginal Deaths in Custody Royal Commission. Her return to the film industry came later in life and in a position of greater strength. She did not act again, taking instead a role behind the scenes, as a 'co-ordinator' for Aboriginal people involved in movies. ${ }^{101}$ Asked to act in Tracey Moffatt's Night Cries, a short film possibly inspired by or referencing Jedda, she refused. ${ }^{102}$ Kunoth-Monks later returned to Utopia Station with her family to live a traditional life. Speaking on Message Stick in 2005, she noted that she was 'not an actress', and that her 'purpose now is to retain our language and our land' and to 'hold onto our corroboree and our rituals' ${ }^{103}$

Kunoth-Monks' journey from acting to activism was paralleled by a general shift in descriptions of her in the print media from depiction as a pretty, charming and shy young glamour girl to portrayal as a confident, outspoken or even formidable woman. In the Bulletin in 1990 she was termed 'impossible to ignore' when she had 'a full head of steam' ${ }^{104}$ She was described in the Sydney Morning Herald the same year as 'a formidable woman', while in the Territory Digest she was referred to as a '53 year-old firebrand' whose 'outspoken rhetoric seems contrary to her kind nature'. ${ }^{105}$ Yet she did not escape Jedda, as her starring role in the film was referenced over and over to remind readers of her 1950s fame outside the Northern Territory. Ben Hills, writing in the Sydney Morning Herald in 1990 on problems in Alice Springs, maintained that media representatives wanted to speak to her not 'because she is a big wheel in the official Aboriginal organisations' but because she was best known to the wider public as the star of Jedda. ${ }^{106}$ Reports on her having joined and left the convent, her subsequent job in Aboriginal Affairs and her marriage all referred to her in their headlines as 'Jedda', blurring the distinction between her filmic character and herself. ${ }^{107}$ This blurring fell away in the print media over the years in favour of references to her as being originally made famous as a film star, a trend with a continuing thread of emphasis on the film as the basis of her celebrated status.

\footnotetext{
99 Chryssides 1993: 196-197.

100 Chryssides 1993: 197-198.

101 Chryssides 1993: 175.

102 Chryssides 1993: 202.

103 'Rosalie's Journey', Message Stick, 18 February 2005.

104 'A legend laments', Bulletin, 12 June 1990: 46.

105 Ben Hills, 'Agony of the Alice', Sydney Morning Herald, 2 June 1990: Spectrum section, 71; Dennis Schulz, 'Walk against grog', Territory Digest 12(3), September 1990: 3-4.

106 Ben Hills, 'Agony of the Alice', Sydney Morning Herald, 2 June 1990: Spectrum section, 71.

107 Julia Adams, 'Jedda: she now helps Aboriginals across the "society gap"', Herald, 14 November 1970: 37; Maureen Bang, '“Jedda” and her foster family', Australian Women's Weekly, 9 June 1971: 2-3; Vincent Basile, 'Instant motherhood for Jedda', Age, 14 May 1971: 1; “Jedda” joins church order', Newcastle-Sun, 15 August 1960: 2; 'Jedda the bride', Herald, 3 January 1970: 3.
} 
Over the years since the release of Jedda, various writers have reflected on the impact of the film on Kunoth-Monks' later life. In her memoirs, Elsa Chauvel wrote of her relief at Kunoth-Monks having found 'peace and fulfilment' in the church, because she had been concerned about the impact on Kunoth-Monks of her time spent in the filmmaking world and its 'publicity and limelight', particularly given that there might be no more work for Aboriginal actors. Starring in a film, Elsa felt, was of benefit to Kunoth-Monks, giving her opportunities and allowing her to avoid working as a domestic and marrying 'a member of her tribe' or 'a half-caste white man'. Elsa wrote patronisingly that she was 'proud indeed of the pretty brown Aranda girl, who worked so loyally beside Charles and me' and who went on to work in which she 'strove to uplift and improve the standing of her people' ${ }^{108}$ She contrasted this with the early and tragic death of Wilson, and that of artist Albert Namatjira, although acknowledging that the pressure of extreme publicity, adulation and limelight' could cause tragedies for white people too. ${ }^{109}$ As Schlunke observed, Elsa thus constructed herself 'as having created "Ngarla's" life beyond the making of the film' and her actions as having 'precipitat[ed] Kunoth-Monks' later successes'. ${ }^{110}$ John Ramsland and Christopher Mooney likewise emphasised the film's role in her life, contending that starring in Jedda and being a celebrity 'made her a prominent figure ... in Aboriginal affairs amongst her own people'. ${ }^{111}$ Kunoth-Monks herself was quoted in 1997 saying that ' $[\mathrm{m}] \mathrm{y}$ life has been dominated by Jedda'. ${ }^{112}$ While she acknowledged in one interview that without being cast as Jedda she might have been married at a younger age to someone not of her choosing, and that she might have been less 'eloquent and expressive', she suggested in another that '[t]he positive aspect' of the experience was 'the geographical awareness' she gained from her travels. ${ }^{113}$ Although not sorry to have acted in Jedda since it 'made me aware Australia was a big country' and it 'showed Australia that two Aboriginal actors could play the lead quite competently', she once said that she became:

fed up sometimes when people ask me to talk about Jedda. I tell them 'Jedda', the person, fell off a cliff. She's dead. Jedda was a small part of my life. ${ }^{114}$

Indeed, far from seeing the film as a benefit to her later work, she was quoted by Hills in 1990 saying that she got 'a bit sick of that being dragged up all the time' because '[w]e' re here to talk serious stuff' ${ }^{115}$ For Kunoth-Monks, Jedda was a far less significant part of her life than it has been for many other commentators.

108 Chauvel 1973: 140.

109 Chauvel 1973: 140-141.

110 Schlunke 1993: 12.

111 Ramsland and Mooney 2006: 148.

112 Richard Jinman, 'From Utopia to return of Jedda', Sydney Morning Herald, 27 September 1997: 15.

113 Chryssides 1993: 203; Kunoth-Monks, interview, tape 3.

114 Chryssides 1993: 203.

115 Ben Hills, 'Agony of the Alice', Sydney Morning Herald, 2 June 1990: Spectrum section, 71. 


\section{Conclusion}

Examining and weaving together the multiple and often conflicting narratives which surround the making of Jedda, and exploring the experiences of its Aboriginal stars, provides a much more complex and multi-hued story than that which is usually evident in writing about the film. I have focused in this paper on the experiences of Kunoth-Monks, interweaving her memories of making the film and her reflections upon her brief turn as a film star with narratives found in publicity material about the film, in the print media, in the memoir of Elsa Chauvel and in other texts. As an actress with a leading role, KunothMonks figured in the print media as a star, depicted in glamorous terms and placed within white western discourses of beauty, femininity and modernity. At the same time, as one of the first Aboriginal film stars, she was portrayed in ways that mobilised popular racial discourses, particularly discourses about assimilation, primitivity and exoticism. Until she spoke of her own recollections in later interviews, Kunoth-Monks often had little input into these constructions of her story, which were often distant from her actual experiences of being a film star. Understanding the multiplicity of narratives about making the film, the ambiguous experiences of its Aboriginal stars, and their mobilisation in the print media as the first Aboriginal film stars, adds greatly to our understandings of Jedda. Such a multi-hued history reveals Jedda as not merely a classic Australian film, nor even a rich text for understanding ideas of race and gender with wide currency at the time of its release, but also as an unstable moment, a moment of volatile encounters, fluid possibilities and shifting meanings.

\section{Acknowledgements}

This paper has benefited from the comments of Bronwen Douglas, Ann McGrath, Tom Griffiths and Chris Ballard, as well as from those who provided feedback when it was first given as a seminar in the History Program in the Research School of Social Sciences at the Australian National University and as a paper at the Film and History in the Pacific Workshop held in Canberra in 2008. I also wish to thank the referees, whose helpful suggestions have improved the article.

\section{References}

\section{Newspapers and magazines}

Advertiser, Adelaide

Age, Melbourne

Australian Women's Weekly

\section{Bulletin}


Centralian Advocate

Dawn

Daily Telegraph

The Film Weekly

Herald, Melbourne

New York Times

Newcastle-Sun

News Weekly

Northern Territory News

Sydney Morning Herald

Territory Digest

Times, London

Weekly Times

\section{Secondary sources}

Ackland, Craig 2001, 'The interactions of Aboriginality, media and education', Journal of Australian Indigenous Issues 4(4): 13-28.

Anderson, Kay 2007, Race and the Crisis of Humanism, Routledge, London and New York.

Beckett, Jeremy 1993, 'Sarah McMahon's mistake: Charles Chauvel's Jedda and the assimilation policy', The Olive Pink Society Bulletin 5(2): 15-18.

Brister, Charles 1995, 'A history of the Star Theatre of Darwin', Journal of Northern Territory History 6: 35-43.

Carlsson, Susanne Chauvel 1989, Charles and Elsa Chauvel: Movie Pioneers, University of Queensland Press, St. Lucia.

- 2005, 'Jedda: new life for a fifties classic', Metro Magazine 144: 50-53.

Chauvel, Charles et al c1954, Eve in Ebony: The Story of 'Jedda', [Columbia Pictures Proprietary], [Sydney].

Chauvel, Elsa 1973, My Life with Charles Chauvel, Shakespeare Head, Sydney. 
Chryssides, Helen 1993, Local Heroes, Collins Dove, North Blackburn.

Cunningham, Stuart 1987, 'Charles Chauvel: the last decade', Continuum 1(1): 26-46.

- 1991, Featuring Australia: The Cinema of Charles Chauvel, Allen and Unwin, Sydney.

- and William D Routt (eds) 1989, “"Fillums became films” (1940-1956)', in Cinema in Australia: a documentary history, Ina Bertrand (ed), New South Wales University Press, Kensington: 177-240.

Douglas, Bronwen and Chris Ballard (eds) 2008, Foreign Bodies: Oceania and the Science of Race 1750-1940, ANU E Press, Canberra.

Grant, Gerry 1956, “"Jedda”', Overland 6 (February): 7-8.

Haskins, Victoria 2001-2002, 'Turning magpies into canaries: the stories behind the Jedda portraits', World of Antiques and Art 62 (December-June): 98-101.

Jennings, Karen 1993, Sites of Difference: Cinematic Representations of Aboriginality and Gender, Australian Film Institute, Research and Information Centre, South Melbourne.

Johnson, Colin 1987, 'Chauvel and the centring of the Aboriginal male in Australian film', Continuum 1(1): 47-56.

Kennedy, Jennifer J nd, 'Harney, William Edward (1895 - 1962)', in Australian Dictionary of Biography, online edition, Australian National University, updated continuously, accessed 2 March 2007: <http:/ / www.adb.online.anu. edu.au/biogs/A140442b.htm>

Klinger, Barbara 1997, 'Film history terminable and interminable: recovering the past in reception studies', Screen 38(2), (Summer): 107-128.

Kunoth-Monks, Rosalie, interview with Robin Hughes, conducted 10-12 July 1995, Utopia, Northern Territory, accessed 14 November 2008: <http:/ / www. australianbiography.gov.au/subjects/kunothmonks>

Landman, Jane 2006, The Tread of a White Man's Foot: Australian Pacific Colonialism and the Cinema, 1925-62, Pandanus, Canberra.

Langton, Marcia 1993, "Well, I heard it on the radio and I saw it on the television", an essay for the Australian Film Commission on the politics and aesthetics of filmmaking by and about Aboriginal people and things, Australian Film Commission, North Sydney. 
McGrath, Ann 1990, 'The white man's looking glass: Aboriginal-colonial gender relations at Port Jackson', Australian Historical Studies 24(95): 189-206.

McGregor, Russell 1997, Imagined Destinies: Aboriginal Australians and the Doomed Race Theory, 1880-1939, Melbourne University Press, Carlton South.

McKee, Alan 1997, 'The generic limitations of Aboriginality: horror movies as case study', Australian Studies 12(1), (Summer): 115-138.

McQueen, Humphrey 2005, 'Making Jedda: attitudes towards indigenous issues around a 1950s film production', in Encounters: Meetings in Australian Music, Vincent Plush, Huib Schippers and Jocelyn Wolfe (eds), Queensland Conservatorium Research Centre, South Brisbane: 60-63.

Molloy, Bruce 1990, Before the Interval: Australian Mythology and Feature Films, 1930-1960, University of Queensland Press, St Lucia.

Monks, Rosie Kunov [sic] 1998, “"Jedda” and its star', in Voices from a Vanishing Australia: Recollections of the Way Things Used to Be, ABC Enterprises for Australian Broadcasting Corporation, Crows Nest, New South Wales: 132136.

Ramsland, John and Christopher Mooney 2006, Remembering Aboriginal Heroes: Struggle, Identity and the Media, Brolga, Melbourne.

Rintoul, Stuart 1993, The Wailing: A National Black Oral History, William Heinemann Australia, Port Melbourne.

'Rosalie's Journey', Message Stick, ABC Television, screened 18 February 2005, transcript translated from Arrernte, updated 29 April 2005, accessed 28 August 2006: <http:/ / www.abc.net.au/message/tv/ms/s1307580.htm>

Schlunke, Katrina 1993, 'Imaging the imagined: stories of Jedda', The Olive Pink Society Bulletin 5(2), (December): 9-13.

Walsh, Mike 2005, 'Jedda', Metro Magazine 144: 54-57.

Watson, Paul J 1996, 'The real north? Jedda and the centring of the Australian male', Northern Perspective 19(2): 16-24. 